nach ist der Faktor, der die Immunfunktion des Körpers im ganzen herabsetzen kann, von unspezifischer Natur. Unser Untersuchungsergebnis bestätigt das Vorhandensein einer Substanz, welche die Transformation der Lymphozyten verhindert. Der Mechanismus kann, wie Hattler, et al meinen, darin bestehen, daß diese Substanz die Oberfläche der Lymphozyten bedeckt und dadurch die Transformation zu Lymphoblasten verhindert. Zur Zeit wird angenommen, da $\beta$ die Immunosuppressionsfaktoren menschlicher und experimenteller Tumoren, gleicher Tierarten mit verschiedenen Tumoren, eines Tumors mit mehreren immunosuppressiven Faktoren verschieden sind. Das weist auf die Kompliziertheit dieser Faktoren hin. Unsere Untersuchung zeigt außerdem, daß eine bestimmte Menge des Immunosuppressionsfaktors auch im Serum von gesunden Frauen und Patientinnen mit gutartigen Tumoren zu finden ist. Fernerhin fanden wir in den Seren von 16 Schwangeren in der Frühgestationsperiode eine durchschnittliche Immunosuppressionsrate von $18,36 \%$. Es scheint wichtig zu sein, die Natur dieses Faktors, seinen Wirkungsmechanismus einschließlich seines Einflusses auf verschiedene Immunozyten, seine Verteilung im Organismus bzw. die Ausscheidung aus dem Körper weiter zu studieren.

Aufgrund unserer klinischen Beobachtungen können wir behaupten, da $\beta$ die Lymphozytentransformationsrate bis zu einem gewissen Grade die Immunfunktion des Körpers widerspiegelt. Leider ist diese Untersuchungsmethode nicht empfindlich genug. Nach Hellström ist im Serum von Kranken mit einem bösartigen Tumor von 1 bis $1,5 \mathrm{~mm}$ Durchmesser bereits der Immunosuppressionsfaktor nachweisbar. Nach operativer Entfernung des Tumors verschwindet dieser Faktor, oder er nimmt mengenmäßig ab. Bei Tumorrezidiv kommt der Faktor entweder wieder zum Vorschein, oder er nimmt mengenmäßig zu. Es könnte für die Praxis der Tumorimmunotherapie von gewisser Bedeutung sein, wenn es gelänge, Heilmittel aufzufinden, welche den Immunosuppressionsfaktor zerstören bzw. unwirksam machen können.

\title{
Heterotopic Heart Allograft in Rats
}

\author{
Chen Zhonghua (陈忠华) \\ Institute of Organ Transplantation, \\ Wuhan Medical College, Wuhan
}

Heterotopic heart transplantation in rats is selected as a model for transplant researches in many countries in recent years. Mcdified Abbott-Ono's method was employed in the Institute of Organ Trarsplantation of Wuhan Medical College; and from Dec. 26, 1980 to Apr. 25, 1981, 74 experiments (54 preparatory and 20 formal experiments) were performed.

Hybrid male rats, weighing 250-300 grams, were used as recipients and donors. Only the clear operation under ether anesthesia is needed. By using micro-surgical technique $(10 \times)$, all vascular anastomoses were done satisfactorily. The thoracic aorta of the donor heart was connected end-to-side to the abdominal aorta of the recipient and the pulmonary artery of the donor heart connected end-to-side to the abdominal inferior vena cava of the recipient. Other vessels of the donor heart were ligated. Within 2 minutes following revascularization, effective ventricular contraction appears spontaneously. No artificial pacemaker was needed for resuscitation. The operation can be completed within 90 minutes by a single operator.

Of the 20 transplanted animals, 14 survived more than 7 days (70\%) and 8 more than 14 days $(40 \%)$ without immunosuppressive therapy, with the longest survival time being 185 days after transplantation and the mean survival time 27 days. There is one still alive (122 days after grafting) with effective heart beat and normal ECG.

Pathological examinations show that 12 transplanted hearts $(60 \%)$ have definitive histological evidences of acute rejection. 